\title{
Earnings Quality and Accruals over Company'S Life Cycle
}

\author{
Lucia Michalkova ${ }^{1, *}$ \\ ${ }^{1}$ Department of Economics, Faculty of Operation and Economics of Transport and Communications, \\ University of Zilina, Univerzitna 1, 01026 Zilina, Slovakia
}

\begin{abstract}
.
Research background: The increasing number of bankruptcies and the growing risk of financial distress highlight the need for quality financial statements, conservative accounting or increase the need for quality tools to detect the occurrence of earnings management. However, the life cycle of a company affects financial performance and key aspects of earnings management, which examined in the international context only to a small extent.

Purpose of the article: The paper examines the impact of the life cycle and country- specific factor on the value of discretionary accruals in the tourism sector in the Visegrad countries, which are among the most vulnerable sectors in the coming economic crisis.

Methods: This study uses the method of two-way analysis of variance with interaction, while also testing the assumptions of the model by normality tests, homogeneity test and post hoc tests (Scheffé and Tukey methods).

Findings \& Value added: Earnings quality changes during the life cycle of a business; whereas in the first stages (introduction, growth) and in decline they use downward earnings management. On the contrary, mature and shake-out companies have enough positive earnings before taxes, which is a prerequisite for tax profit optimization. The level of earnings management in tourism varies significantly at different stages of the life cycle, but also in different countries. The results imply that the qualitative variable corporate life cycle in interaction with the country is an important explanatory variable, the implementation of which can improve the explanatory power of earnings management models in Central European developing countries.
\end{abstract}

Keywords: earnings management; emerging countries; corporate life cycle

JEL Classification: $G 31$; $G 32 ; H 43$

\footnotetext{
*Corresponding author: lucia.michalkova@fpedas.uniza.sk
} 


\section{Introduction}

As during the economic crisis of 2009 and 2020, the global economy is facing an important challenge. Based on the OECD Economic Outlook, September 2020, the global economy is projected to decline by $4.5 \%$ for 2020 and the euro area by $7.9 \%$. In the next period (2021), a modest economic recovery is expected, with growth of 5\% worldwide and $5.1 \%$ within the euro area. However, these predictions mean a better outlook for 2020, the estimate for 2021 is worse by $0.2 \%$ globally and even $1.2 \%$ on a European scale compared to the March Outlook [1]. Euler Hermes [2] adds that despite economic growth, the main insolvency boom will still occur at the end of 2020 and in the first half of 2021. The global insolvency index should reach a record growth of $35 \%$ in 2021 compared to the latest data from 2019. The most dramatic growth is expected in the US (57\%), Brazil $(45 \%)$ or Spain (41\%). A high percentage of bankruptcies is expected by Euler Hermes even in small pro-export oriented Central and Eastern Europe; a record 49\% in Lithuania, 38\% in Slovakia and 34\% in the Czech Republic. Poland and Hungary should be among the less affected countries with $24 \%$ (Poland) and 20\% (Hungary) of insolvencies. The last mentioned countries, with the exception of Hungary, show much higher increases in insolvencies compared to 2019 and also compared to the crisis year of 2009.

The increasing risk of default draws attention to publicly available financial statements (balance sheet, profit and loss statement, cash flow statement), which are the main source of information for stakeholders. The relevance or reliability of these statements may be reduced due to the manipulation of accounting numbers that are used by companies in adverse economic conditions to a greater extent. Inaccurate financial statements tend to misinterpret a company's financial performance and may ultimately result in a cyclical increase in insolvency growth [3]. In contrast, high-quality accounting reporting and high-quality earnings reflect a long-term trend, reflecting a conservative understanding of accounting rules, minimizing one-off items, and cash flow covering profit [4]. Lo [5] directly combines high earnings management with low profit quality. In contrast, Dechow, et al. [6] argue that the definition of quality earnings is ambiguous and there are many candidates for a proxy of quality earnings. Frequently used residuals from accrual models (such as the Jones model, the modified Jones model, Teoh, et al. Model, etc.) have a low $\mathrm{R}^{2}$ and a large number of omitted variables that reduce the reliability of the results.

Stakeholders can detect accrual earnings management through two calculation principles: time-series or cross-section approach. The former is only suitable if the surveyed company has a sufficient history (sufficient accounting information). On the contrary, the cross-section approach is more strongly represented in the professional literature as evidenced by a review by [7]. The point of contention for the application of the cross-section approach is the condition of homogeneous estimation samples. Undertakings operating in the same sector, which are expected to have similar financial characteristics, are commonly used as samples. The inhomogeneity of the normal accrual generating process within an industry has been demonstrated by several studies [8-10]. Businesses in one sector share similar characteristics given by macroeconomic variables and the phase of the industrial life cycle, but do not take into account the uniqueness of companies in terms of business life cycle. Empirical studies [11-13] show that profit manipulation is different at different stages of the company's life cycle, or the estimation of discretionary accruals based on the life cycle. based estimating samples instead of industry based is more accurate.

In this context, the paper examines the impact of the life cycle and country specific factor on the value of discretionary accruals in the tourism sector in the Visegrad countries, which are among the most vulnerable sectors in the coming economic crisis. Net sample of financial indicators of 3650 companies from the last available accounting period 2018 was used, which is the most relevant to the economic situation in 2020. The study adopted a life cycle 
approach from Dickinson [14] and discretionary accruals are quantified based on a modified Jones model. In order to identify the impact of the life cycle phase on the quality of earnings (degree of earnings management), a two-way ANOVA was used, where the second factor was the country's affiliation.

\section{Life cycle theory and corporate financial performance and accruals}

The life cycle of a company is similar to the life cycle of products, with the difference that the company is a mix of different products and other aspects, i.e. defining the life stages of a company on the same scale as a product would be insufficient. Business life cycle theories vary depending on the cause; we distinguish theories focused on the managerial concept and organization of the company and theories focused on financial indicators such as dividend policy, managerial accounting system, takeover activity or business valuation. The latter created a comprehensive business life cycle model, consisting of 6 phases: Start-up, Young Growth, High Growth, Mature Growth, Mature Stable and Decline. Similar to [14], this model describes the behaviour of investment, financial and operational cash flow, in addition to focusing on the description of capital structure, debt capacity and debt value, tax benefits or dividend policy.

From the point of view of the capital structure, Damodaran [15] states that external financing (bank loans, venture capital or trade credits) is used more by younger companies because resources such as shares or marketable debt are unavailable to them. Internal resources are low or negative in the early stages, but may also exceed financial needs after the maturity stage. Debt is gradually gaining in value with the growth of sales and profit, which is reflected in the growth of tax benefits. The stabilization of profit and its predictability in the graduation phase helps to reduce the expected costs of bankruptcy. Dividend policy copies the development of earnings and free cash flow to equity; any type of dividend (regular or special) is paid only from the period of mature growth.

Damodaran [15] mentions, among other things, that the general model of a company's life cycle differs depending on the nature of the company examined. Businesses in the technical sectors have a significantly steeper life cycle curve with a short introduction phase, rapid growth and an equally rapid fall from peak profitability. Compressed life cycle means that rapid growth allows the business to move between large in less time. However, its investment opportunities will reach the highest point much faster and begin to decline. The intensive life cycle causes the investment cash flow to become free cash flow to equity, which is paid out to investors as special dividends or used for buybacks. These companies are much more vulnerable to new competitors in the market with minimal barriers to entry. On the contrary, non-technical enterprises (service enterprises) have a longer life cycle conditioned by a higher connection of customers to the product. The decline phase, like growth, is long-lasting; these businesses have a higher chance of a turn of life cycle.

Dickinson [14] developed a life cycle model based on cash flow. Unlike Damodaran [15] mentioned above or Jovanovic [16] and others she primarily examined cash flow, which should include all the mentioned influences. The company's life cycle includes five phases: Introduction, Growth, Maturity, Shake-out and Decline. Cash flow is divided into operational, investment and financial, a unique combination of these three components defines each of the phases of the life cycle.

In the first phase (Introduction), the company is largely financed through bank debt or, to a lesser extent, by shareholders [17]. Higher external financing associated with negative working capital causes and, with significant investment activity, negative operating cash flow, positive investment cash flow and financial inflow. The company faces high corporate risk (credit and operational). Negative working capital is associated with the growth of 
accruals from current assets (mainly inventories), which causes a significant change in cash sales in the first phase of the life cycle [18]. On the contrary, the value of depreciation has little effect on the total accrual, because so far the company only accumulates fixed assets, whose depreciation is low.

Growing companies, like start-ups, have significant investment activities (negative cash flow) and financing by debt is deepening. Operating cash flow is positive because the growth of inventories is accompanied by the growth of trade credits. Both of these components of the total accrual are growing. The total cash flow reaches a positive value. At this stage, a break-even point occurs, the company becomes profitable, it is able to obtain long-term debt in addition to short-term debt. Dickinson [14] adds that both fixed assets and depreciation are the highest, which increases the value of total accruals.

In accordance with the industrial life cycle, at the stage of maturity there is a maximum of companies that have sufficient knowledge of operational activities and are able to minimize operating costs [16]. Operating cash flow is positive as opposed to investment and financial, which are negative. There is a significant difference between profit and cash flow; cash flow outpaces profit. Growing sales eliminate corporate risk. Mature companies pay large dividends and are not interested in new investments, which is in line with the findings of Damodaran [15] mentioned above. Although companies have easy access to debt at this stage, they also have to pay debt repayments and interest on debts earned in previous periods. Working capital accruals are low because investment in current assets is not significant [18]. This is also reflected in the year-on-year change in cash sales, which are much smaller than in other phases of the life cycle. The negative investment cash flow is also reflected in the lower value of fixed assets and the gradual decline in the value of depreciation.

The shake-out stage is characterized by a gradual decline in profit and stabilization or decline in the number of companies in the market. Growth rates are also declining, causing stock prices to fall [13]. However, [14] points out that there is no clear evidence in the literature about the cash flow pattern of such companies. For this reason, any cash flow pattern other than those defined for the other stages of the life cycle falls within the shakeout. Businesses at this stage can, for example, extend their life cycle by investing in new products or also shrink the business (the company's strategy determines whether the investment cash flow will be outflow or inflow).

In the last stage, the company has all financial characteristics (sales, profit, cash flow) declining; operating cash flow is negative. A negative outlook is not good for shareholders; stock prices are gradually falling. Debt is reduced as a result of debt repayment or the debt may be renegotiated (depending on the strategy, a financial outflow or inflow arises). Investment cash flow is positive because the company sells assets to satisfy debtholders [16]. Investment in working capital is minimal, but the company is trying to raise cash by reducing receivables; cash sales are the highest of all life cycle stages. The sale of assets also reduces the value of fixed assets and small-scale depreciation affects profit or cash flow [18].

The description of both described life cycle models shows that there are significant changes not only in the company's financial performance, but also there is room for profit manipulation (accrual and real earnings management). Moreover, earnings with minimal accounting manipulations are more informative for stakeholders and more predictable [19.20]. Chen [12] notes that accrual models have a higher explanatory power using the life cycle as one of the variables for listed Chinese companies. Zamrudah and Salman [21] found that in the growth phase, accruals play an important role in determining earnings management, while they are not essential in the decline phase. Hastuti, et al. [11] used a sample of Indonesian listed companies; however, according to their findings, the life cycle has no effect on the detection of earnings management. Dickinson, et al. [22] examined the relevance of profit in relation to market value prediction. Extreme performance determines 
the need for quality accounting reported information, especially in the Introduction and Decline phases.

Previous studies have shown that earnings management and quality earnings vary over the life cycle; however, the records focus on Asian countries and listed companies. It is therefore necessary to examine whether the life cycle has an impact on earnings management in unlisted companies and in Central European countries.

\section{Methods}

The aim of this paper is to investigate whether the life cycle affects the position of earnings management in tourism companies in the countries of Central Europe (Visegrad Four). A review of the literature in the previous chapter showed that the financial characteristics of companies at different stages of the life cycle differ, not excluding factors indicating profit manipulation.

In this study, we analysed two factors; in the first place the life cycle stages according to Dickinson [15], in the second place the Country factor. Businesses are divided by country because, based on differences in national tax policies and different accounting rules (regional IFRS / GAAP), we assume different levels of earnings management. The life cycle factor of a company is created on the basis of eight combinations of cash flow, which are divided into five categories corresponding to the stages of the life cycle (introduction, growth, mature, shake-out, decline). The categories and their cash flow patterns are described in Table 1.

Table 1 Cash flow patterns according life cycle stages (source [15])

\begin{tabular}{|l|l|l|l|l|l|l|l|l|}
\hline Cash flow & Introduction & Growth & Mature & \multicolumn{3}{|c|}{ Shake-out } & \multicolumn{2}{c|}{ Decline } \\
\hline Operating & Neg. & Pos. & Pos. & Neg. & Pos. & Neg. & Neg. & Neg. \\
\hline Investing & Neg. & Neg. & Neg. & Neg. & Pos. & Pos. & Pos. & Pos. \\
\hline Financing & Pos. & Pos. & Neg. & Neg. & Pos. & Neg. & Pos. & Neg. \\
\hline
\end{tabular}

The quality of earnings can be examined in various ways as described in [6]. However, earnings management models are the most commonly used proxies that determine whether earnings are manipulated or not. A modified Jones model was chosen, which is one of the most frequently used. Its advantage is that, compared to the original Jones model, it eliminates type I and type II errors. Proxies for earnings management are residuals of an estimated modified Jones model that identify discretionary accruals.

Both factors (qualitative variables) and proxies for earnings management are examined by two-way Anova. The advantage of this method, as opposed to one-way analysis of variance, is the ability to investigate the interaction between the two factors, which reduces the error term. This method is subject to several assumptions (normality of subsets, homogeneity of variances, independence of cases and no outliers). These assumptions are tested by appropriate tests (Kolmogorov-Smirnov test, Levene's test) and outliers were removed by wisorizing at $1 \%$ and $99 \%$ percentile. If the assumptions are not met, then the two-way Anova is tested on a robust basis (with robust standard errors).

The regression form of Anova provides the model described in Eq. 1.

$$
E M_{i}=\mu+\text { Country }_{j}+\text { Life cycle }_{k}+\text { Country } \cdot \text { Lifecycle }_{j \cdot k}+\varepsilon_{i j k}
$$

Where: $E M$ - earnings management (earnings quality) proxy, $i=1,2, \ldots, 3650$ - number of cases in net sample, $j=1,2, \ldots, 4$ - number of country $(1-$ the Czech Republic, $2-$ Hungary, 3 - Poland, 4 - Slovakia), Country $\cdot$ Lifecycle $_{j \cdot k^{-}}$interaction term $(j \cdot k=$ $1,2, \ldots, 20)$

A sample for the study was obtained from the Amadeus database. There are three selection conditions: classification in NACE main section I - Accommodation and food services activities, turnover higher than 100000 euros in 2018 and registered office in one of 
the Visegrad Four countries. 15,295 companies were selected, representing a gross sample. The SPSS program was used to examine the sample and meet the goal of the study.

\section{Results and Discussion}

The first step in the study of the quality of accruals at various stages of the company's life cycle is the analysis of a sample. The gross sample contains 15,295 enterprises, however, enterprises with missing values of financial indicators were detected. These companies were removed from the sample. After the first step of the analysis, the sample had 3650 cases. Removal of outliers was done by wisorizing at $1 \%$ and $99 \%$ percentile. The advantage of this method is the fact that the sample is not reduced. The net sample contained 3650 companies; from their financial data, discretionary accruals were estimated and life cycle phases were assigned according to cash flow patterns. The estimated earnings management proxies were examined based on descriptive statistics as shown in Table 2.

Table 2 Descriptive statistics of earnings management according to country and life cycle stage

\begin{tabular}{|c|c|c|c|c|c|}
\hline Factor & \multicolumn{5}{|c|}{ Earnings management proxy (discretionary accruals) } \\
\hline Country & Mean & Median & Std. Deviation & \% of Total N & N \\
\hline the Czech Republic & 0,0221 & 0,0470 & 0,4588 & $37,80 \%$ & 1381 \\
\hline Hungary & 0,0054 & 0,0164 & 0,1941 & $4,90 \%$ & 180 \\
\hline Poland & 0,0068 & 0,0203 & 0,2434 & $28,40 \%$ & 1035 \\
\hline Slovakia & 0,0559 & 0,0812 & 0,5548 & $28,90 \%$ & 1054 \\
\hline Life cycle stage & & & & & \\
\hline introduction & 0,4018 & 0,2889 & 0,4116 & $7,60 \%$ & 278 \\
\hline growth & 0,0993 & 0,0734 & 0,3228 & $21,00 \%$ & 768 \\
\hline mature & $-0,0748$ & 0,0102 & 0,2992 & $22,80 \%$ & 832 \\
\hline shake-out & $-0,0686$ & 0,0058 & 0,4805 & $39,00 \%$ & 1422 \\
\hline decline & 0,1984 & 0,1331 & 0,4779 & $9,60 \%$ & 350 \\
\hline
\end{tabular}

The mean values of earnings management show that there are differences in the quality of profit in different countries as well as in different phases of the life cycle. On average, Czech and Slovak tourism enterprises increase their reported profit through accruals much more significantly than in Poland than in Hungary. The latter countries manage profits on average to a very small extent. However, the standard deviations show that there is a significant variation in discretionary accruals and that many companies tend to reduce their profits. More broadly, the life-cycle analysis shows the differences between businesses, regardless of country of origin. The most manipulative companies are in the Introduction phase, where they show negative operating cash flow. At this stage, the accounting profit is significantly overestimated; even with regard to the standard deviation, companies use neutral earnings management or significantly overestimate profit over cash flow. In the Growth and Decline phases, while operating cash flows are different, earnings management has a similar positive value with respect to variance. Moreover, the Mature and Shake-out stages show that businesses have enough resources to report lower accounting profits. After reaching the break-even point in the Growth stage, there is an increase in profit and stabilization (elimination) of corporate risk. Stable profit allows companies to obtain additional resources for expansion with low cost of capital, which increases the importance of tax optimization (minimization) of profit. The analysis shows that companies at different stages of the life cycle change their behaviour regarding profit management and the 
importance of tax and profit reduction is directly linked to the cash flow achieved. Nevertheless, descriptive statistics do not take into account the interaction between the country and the life cycle, which Anova examines in more depth.

The first step in analysis of variance is to verify the model's assumptions. The normality of the subsamples was examined by histograms and tested by the Kolmogorov-Smirn test at the level of 0.05 . As shown by the significant difference between the median and the mean (average), this assumption of the model is not fulfilled and the null hypothesis of normality of subsamples was rejected. Second, the assumption of homogeneity of variances would be tested by the Levene's test. Also the null hypothesis was rejected, the variances are heterogeneous. For this reason, a two-way ANOVA with robust standard deviations was used, which eliminates the occurrence of type I error. A summary Anova table for selected factors is shown in Table 3.

Table 3 Summary table of two-way Anova results

\begin{tabular}{|c|c|c|c|c|c|c|}
\hline Source & $\begin{array}{c}\text { Type III } \\
\text { Sum of } \\
\text { Squares }\end{array}$ & df & Mean Square & F & Sig. & $\begin{array}{c}\text { Partial } \\
\text { Eta } \\
\text { Squared }\end{array}$ \\
\hline $\begin{array}{c}\text { Corrected } \\
\text { Model }\end{array}$ & $81,384 \mathrm{a}$ & 19 & 4,283 & 25,802 & 0,000 & 0,119 \\
\hline Intercept & 10,733 & 1 & 10,733 & 64,653 & 0,000 & 0,017 \\
\hline Country & 1,997 & 3 & 0,666 & 4,009 & 0,007 & 0,003 \\
\hline Life cycle & 26,479 & 4 & 6,620 & 39,876 & 0,000 & 0,042 \\
\hline $\begin{array}{c}\text { Country * Life } \\
\text { cycle }\end{array}$ & 5,741 & 12 & 0,478 & 2,882 & 0,001 & 0,009 \\
\hline Error & 602,612 & 3630 & 0,166 & & & \\
\hline Total & 686,600 & 3650 & & & & \\
\hline $\begin{array}{c}\text { Corrected } \\
\text { Total }\end{array}$ & 683,996 & 3649 & & & & \\
\hline
\end{tabular}

R Squared =,119 (Adjusted R Squared $=, 114$ )

The results of the model indicate that both main effects (Country and Life cycle) are significant and the quality of reported profit varies in different Central European countries as this variable varies depending on the reported cash flow pattern. However, both of these factors interact, i.e. the level of earnings management at different stages of the life cycle

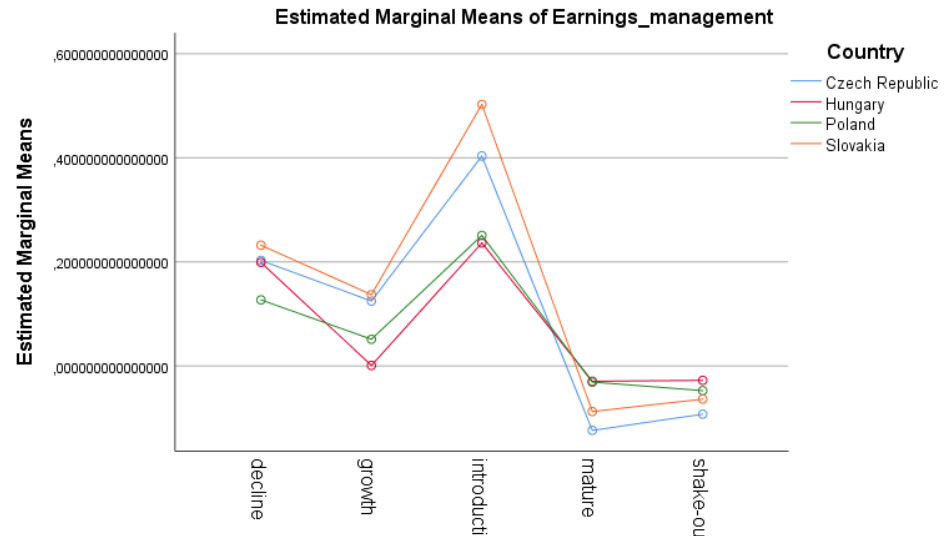

Fig. 1 Interaction effect of Life cycle and Country 
varies in the countries analysed. Partial Eta squared expresses the explanatory ability of the factor; the interaction between factors explains only $0.09 \%$ of the variability of discretionary accruals compared to the explanatory capacity of the life cycle proxy, which explains up to $4.2 \%$ of the variability. Weak interaction effect is shown in Fig. 1.

Fig. 1 proves that there is an interaction between the analysed factors, but this interaction is weak because the lines in the graph are almost parallel. The differentiation of life cycle stages allows a deeper analysis of this factor with respect to the country. Czech and Slovak companies in tourism show similar values of earnings management in all phases of the life cycle. Similarly, Polish and Hungarian companies have similar characteristics, except for the last stages of the life cycle, in which Hungarian companies manipulate accounting profits to a greater extent.

Significant differences between individual countries or phases of the life cycle in the graph are in line with the results in Tab. 2. The last phase of life cycle analysis and earnings management is verification of the difference between the quality of profit according to selected factors. As the Country factor had a weak explanatory power, the Life cycle factor was examined first as the main effect. In accordance with Fig. 2 it is confirmed that there are significant differences between the quality of profit in the life cycle stages, except for the mature and shake-out stages, where companies show an accounting decrease in profit that is not significantly affected by changes in cash flow pattern and market conditions.

However, a deeper analysis of the quality of reported profits by country and life cycle shows deeper differences between enterprises, which is described in Table 4.

Table 4 Summary of significant differences (post hoc tests) between earnings quality in the central European countries

\begin{tabular}{|c|c|c|c|c|}
\hline $\begin{array}{c}\text { Country } \\
\text { significant difference } \\
\text { (post hoc tests) }\end{array}$ & $\begin{array}{c}\text { the Czech } \\
\text { Republic }\end{array}$ & Hungary & Poland & Slovakia \\
\hline introduction - growth & H1 & H1 & H1 & H1 \\
\hline introduction - mature & H1 & H1 & H1 & H1 \\
\hline introduction - shake-out & H1 & H1 & H1 & H1 \\
\hline introduction - decline & H1 & H0 & H1 & H1 \\
\hline growth - mature & H1 & H0 & H1 & H1 \\
\hline growth - shake-out & H1 & H0 & H1 & H1 \\
\hline growth - decline & H0 & H1 & H0 & H0 \\
\hline mature - shake-out & H0 & H0 & H0 & H0 \\
\hline mature - decline & H1 & H1 & H1 & H1 \\
\hline shake-out - decline & H1 & H1 & H1 & H1 \\
\hline
\end{tabular}

Czech, Slovak and Polish tourism companies do not show differences in profit quality between growth and decline, or between mature and shake-out. These results indicate that both rising and falling companies have low operating profit, which is crucial. Growing businesses are using looser accounting rules to increase profits in order to be able to obtain additional sources of financing. Conversely, declining firms are increasing their accounting profit in order to improve their financial position and reduce the cost of capital and credit risk. Hungarian companies show a lower impact of the life cycle on the quality of profit, which shows low differences between the quality of profit in stages with negative operating cash flow.

In conclusion, we can state that this model, like Chen [12], proved a significant impact of the life cycle on the level of earnings management, the value of accruals and the quality of 
profit. However, it should be noted that these characteristics vary from country to country. With this in mind, the life cycle of a company can be an important variable in estimating the quality of profit of stakeholders and creating a model of earnings management of companies in Central European countries.

\section{Conclusion}

The current economic situation in Europe and in the world shows that a high percentage of companies are directly or indirectly at risk of bankruptcy; businesses are subject to a high risk of financial distress. The threat of bankruptcy highlights the need for quality financial statements and the minimization of discretionary accruals. The estimation of earnings management is conditioned by many factors, of which financial performance and the associated stage of the company's life cycle have a significant position.

This study looked at the impact of the life cycle stage on the quality of earnings and sheds new light on the problem of estimating earnings management in the Visegrad Four countries. The sample of 3,650 tourism enterprises examined the impact of life cycle stages and country (accounting, tax and other macroeconomic aspects of the country) on the value of discretionary accruals according to the modified Jones model. The results of the two-way Anova model indicate that both mentioned influences have a significant effect on the level of profit manipulation; earnings management differs significantly at different stages of the life cycle. Mature and shake-out companies use more significant downward earnings management techniques, in other phases managers tend to increase profits. The country factor has a lower impact on differences in profit quality; Slovak and Czech companies increase accounting profit to a similar extent. On the contrary, Hungarian companies differ significantly from the others analysed, which may be due to different accounting rules or a significantly smaller size of the sub-samples. In general, it can be stated that the phase of the company's life cycle is one of the main qualitative influences of the level of earnings management, but it should be assessed at the same time as the country-specific conditions of the company. The inclusion of these two factors in the model could improve the explanatory power of current accrual earnings management or it can be a decisive factor in creating an earnings management model in the conditions of unlisted companies in Central and Eastern Europe.

Since the focus of the study was on accrual based earnings management; the area of real earnings management from the point of view of life cycle is not examined. Given that real earnings management (REM) has an impact on cash flow in all its forms, it can also affect the inclusion of the company in the life cycle according to Dickinson [15]. Nevertheless, future work clarifying the phenomenon of life cycle and accrual and real earnings management will need to be performed.

This paper is an output of science project the Slovak Research and Development Agency - Grant NO. APVV-17-0546 Variant Comprehensive Model of Earnings Management in Conditions of the Slovak Republic as an Essential Instrument of Market Uncertainty Reduction.

\section{References}

1. OECD (2020). OECD Economic Outlook, Interim Report September 2020. Paris: OECD Publishing.

2. Euler Hermes (2020, July, 16). Calm before the storm: covid-19 and the business insolvency time bomb. Euler Hermes. Retrieved from: https://www.eulerhermes.com/content/dam/onemarketing/ehndbx/eulerhermes_com/en _gl/erd/publications/pdf/Final-2020_07_16_InsolvencyTimeBomb.pdf 
3. Kliestik, T., Valaskova, K., Nica, E., Kovacova, M., Lazaroiu, G. (2020). Advanced methods of earnings management: monotonic trends and change-points under spotlight in the Visegrad countries. Oeconomia Copernicana, 11(2), 371-400.

4. Dichev, I.D., Graham, J.R., Harvey, C., Shiva, R. (2013). Earnings quality: Evidence from the field. Journal of Accounting and Economics, 56(2), 1-33.

5. Lo, K. (2008). Earnings management and earnings quality. Journal of Accounting and Economics, 45(2-3), 350-357.

6. Dechow, P., Ge, W., Schrand, C. (2010). Understanding earnings quality: a review of proxies, their determinants and their consequences. Journal of Accounting and Economics, 50(2-3), 344-401.

7. Callao, S., Jarne, J.I., Wroblewski, D. (2017). Detecting earnings management investigation on different models measuring earnings management for emerging eastern European countries. International journal of research - Granthaalayah, 5(11), 222-259.

8. Owens, E.L., Wu, J.S., Zimmerman, J. (2017). Idiosyncratic Shocks to Firm Underlying Economics and Abnormal Accruals. The Accounting Review, 92(2), 183-219.

9. Ecker, F., Francis, J., Olsson, P., Schipper, K. (2013). Estimation sample selection for discretionary accruals models. Journal of Accounting and Economics, 56(2-3), 190-211.

10. Durana, P., Valaskova, K., Chlebikova, D., Krastev, V., Atanasova, I. (2020). Heads and Tails of Earnings Management: Quantitative Analysis in Emerging Countries. Risks, $8(2), 1-21$.

11. Hastuti, T.D., Ghozali, I., Yuyetta, E.N.A. (2017). The effect of company life cycles on the accruals earnings management with internal control system as moderating variable. Polish journal of management studies, 15(1), 66-75.

12. Chen, T. (2016). Internal control, life cycle and earnings quality. Open Journal of Business and management, 4, 301-311.

13. Hribar, P., Yehuda, N. (2015). The Mispricing of Cash Flows and Accruals at Different Life-Cycle Stages. Contemporary Accounting Research, 32(3), 1053-1072.

14. Dickinson, V. (2011). Cash Flow Patterns as a Proxy for Firm Life Cycle. The Accounting Review, 86(6), 1969-1994.

15. Damodaran, A. (2018). The corporate life cycle: growing up is hard to do! People.Stern. Retrieved from: http://people.stern.nyu.edu/adamodar/pdfiles/country/ corporatelifecycleLongX.pdf

16. Jovanovic, B. (1982). Selection and the Evolution of Industry. Econometrica, 50(3), 649-670.

17. Jensen R., Thursby, M. (1986). A strategic approach to the product life cycle. Journal of International Economics, 21(3-4), 269-284.

18. Liu, M. (2007, September 11). Accruals and Managerial Operating Decisions Over the Firm Life cycle. SSRN. Retrieved from: https://papers.ssrn.com/sol3/ papers.cfm?abstract_id=1013536

19. Valaskova, K., Gavurova, B., Durana, P., Kovacova, M. (2020). Alter Ego Only Four Times? The Case Study of Business Profits in the Visegrad Group. E\&MEconomics and Management, 23(3), 101-119.

20. Siekelova, A., Podhorska, I. (2020). Earnings Indicators under the Condition of Globalization. 19th International Scientific Conference Globalization And Its SocioEconomic Consequences 2019 - Sustainability In The Global-Knowledge Economy. (Article Number 01031). Rajecke Teplice: SHS Web of Conferences.

21. Zamrudah, R., Salman, K.R. (2013). Earnings management prediction (a study of company's life cycle). The Indonesian Accounting Review, 3(2), 107-120.

22. Dickinson, V., Kassa, H., Schaberl, P.D. (2018). What information matters to investors at different stages of a frim's life cycle? Advances in Accounting, 42, 22-33. 